\title{
Hybridization and Genetic Diversity in Wild Apple (Malus sylvestris (L.) MILL.) from Various Regions in Germany and from Luxembourg
}

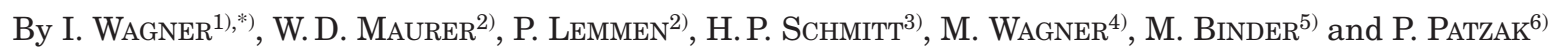

(Received 27 $7^{\text {th }}$ May 2013)

\begin{abstract}
Malus sylvestris is the only apple species native to Central Europe. Its genetic integrity may be threatened by hybridization with the cultivated apple (Malus $\times$ domestica). A total of 883 genotypes, 477 putative wild apples in Germany and Luxembourg and 406 old to modern cultivars has been investigated. Wild apples growing in Germany originated from Rhineland-Palatinate, North Rhine-Westphalia, Saxony-Anhalt and Saxony. The genetic structure was analysed at ten isozyme marker loci, and morphology was studied by fruit size, leaf pubescence, and a complex morphological description performed in advance. A model-based cluster analysis applied to all nuclear data resulted in two clearly differentiated gene pools for putative wild and cultivated apples with moderate proportions of admixture in the wild group on average (0.138 total, 0.111 German sample). At the individual level, the percentages of both hybrids and feral cultivars together ranged from $2.3 \%$ in Rhineland-Palatinate to $28.8 \%$ in Luxembourg. The intraspecific variability in fruit diameter ranged from 21 to $40 \mathrm{~mm}$, and that in leaf pubescence in autumn ranged from score 0 to score 1 . No single morphological trait of a specimen appeared to be sufficient for identification. Even the correspondence between the complex morphological and complex genetic determinations for individuals did not exceed $93 \%$ in pure wilds and $64 \%$ in hybrids. Genetic variation in pure wild apple is high (species level: $\mathrm{P}=90 \%, \mathrm{~A} / \mathrm{L}=3.1, \mathrm{He}=0.369$ ). Allelic differentiation $\delta$ was 0.089 , pairwise genetic distance $\left(\mathrm{d}_{0}\right)$ ranged from 0.065 to 0.148 among five samples. Correspondence between genetic and geographic distance of populations was observed to a certain extent.
\end{abstract}

Key words: Malus sylvestris, Malus $\times$ domestica, introgression, gene flow, genetic variation, genetic differentiation, isozymes, morphology, conservation, biodiversity.

\section{Introduction}

Malus sylvestris (L.) MILL. is a forest fruit tree belonging to the family Rosaceae. This species has a wide geo-

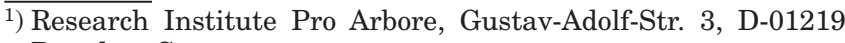
Dresden, Germany.

2) Research Institute for Forest Ecology and Forestry of Rhineland-Palatinate, Hauptstr. 16, D-67705 Trippstadt, Germany.

3) Landesbetrieb Wald und Holz NRW (former LÖBF NRW, Forest Gene Bank, D-59821 Arnsberg), Germany.

4) Administration de la Nature et des Forêts, 16, Rue Eugene Ruppert, L-2453, Luxembourg.

5) Tharandt Botanic Garden and Arboretum, Pienner Str. 8, D-01737 Tharandt, Germany.

6) FÖLV Biosphere Reserve 'Mittelelbe', Johannisstr. 18, D-06844 Dessau, Germany.

*) Corresponding author: IRIS WAGNER. Phone/Fax: +49 3514759619. E-Mail: IrisWagner@aol.com
}

graphic distribution (KUTZELNIGG, 1995), similar to that of Quercus robur, and it is the only apple species native to Central Europe. Wild apple trees often have expanded crowns resembling those of bushes. By virtue of their height classification, biologically they constitute the connecting link between shrubs and trees. Individual trees can grow up to $10 \mathrm{~m}$ tall with trunk diameters of $23-45 \mathrm{~cm}$ and can live to 80 to 100 years. They rely on insect pollination and seeds are dispersed by mammals, birds, water courses and human activity. Trees exist along the edge of forests, in farmland hedges or on very extreme, marginal sites. A detailed description of the species is given in WAGNER (2005).

Wild apple is a very rare tree species. It often has a scattered distribution pattern, occurring as single individuals or in small groups. Intact populations do exist very rarely in nature. Economic insignificance and biological features are the main reasons for its nearly extinct status. Timber and fruit are of no economic value. The species' competitive ability is low due to its low height growth and high light requirements.

Wild apple is considered to be seriously endangered (BLE, 2013). One major threat to its genetic integrity may be the gene flow between wild and cultivated apples. $M$. $\times$ domestica Borkh. can be regarded as major source of hybridization and the cause of introgression of the $M$. sylvestris gene pool throughout Europe due to wide-spread domestication of apples (probably since ancient times). Ornamental cultivars derived from many different Malus species (see COART et al., 2003) may have contributed genes as well, but this appears unlikely for adult wild apples investigated in this study because the use of ornamentals in the landscape has occurred only recently. Thus edible cultivars are a suitable reference for wild apples living today, which are supposed to represent the native species. Furthermore, their suitability as reference lies in the fact that M. sylvestris probably did not contribute initially to the genetic make-up of domesticated apples. According to MORGAN and RICHARDS (1993) M. sylvestris contributed few genes to $M . \times$ domestica. Recently there is a controversy about the real contribution of $M$. sylvestris to the domestic germplasm (VELASCO et al., 2010; MiCHELETTI et al., 2011; CoRNILle et al., 2012). The debate is ongoing and the issue needs further study (HARRISON and HARRISON, 2011). Nevertheless, the most widely accepted theory currently is that $M$. sieversii, which is native to the forests of central Asia, is the most likely primary progenitor of cultivated apples (HoKANSON et al., 1997; ROBINSON et al., 2001; HARRIS et al., 2002; VELASCO et al., 2010; CoRNILle et al., 2012). Due to domestication activity over hundreds of years, suture zones were artificially 
created between two species of the same genus, which were in fact (originally) geographically separated. Thus introgression was initiated (HATTEMER und GREGORIUS, 1993) throughout the distribution area of $M$. sylvestris.

At first, hybridization has been studied foremost in three European countries (WAGNER and WEEDEN, 2000; WAGNER et al., 2004; COART et al., 2003 and 2006; LARSEN et al., 2006). In Germany investigations have focused on subgroups, rather than on individuals on a large scale. Thus in this study, the genetic and morphological characteristics of a large sample of apples were analysed to investigate hybridization at the individual tree level. Additionally population genetic analyses have been performed to gain better insight into apples originating from quite different regions.

Results presented provide a summary of comprehensive genetic and some morphological inventories of apple samples in Germany and Luxembourg.

Major questions addressed in this study are:

(1) To what extent are the nuclear gene pools of M. sylvestris and $M . \times$ domestica admixed in Germany and Luxembourg?

(2) How large is the variability in fruit size and leaf pubescence in pure $M$. sylvestris?

(3) Is there any correspondence between morphological and genetic characters?

(4) Is genetic variation considerable within and between samples of pure wild apples?

\section{Materials and Methods}

\section{Plant material}

In total, 883 genotypes of $M$. sylvestris and $M$. $\times$ domestica were analysed. The 477 trees initially selected as $M$. sylvestris came from two European countries; Germany (418) and Luxembourg (59). The apple trees growing in Germany originated from four states, from the western states of Rhineland-Palatinate (86) and North Rhine-Westphalia (100), and from the eastern states of Saxony-Anhalt (124) and Saxony (108). Apple trees selected from Luxembourg and North Rhine-Westphalia primarily comprised single-tree or clone collections which were sampled throughout these regions. Apple trees from Rhineland-Palatinate, Saxony-Anhalt and Saxony represented in situ reproductive populations. Where the entire population was not sampled, individuals were sampled randomly within each population.

In Rhineland-Palatinate and Saxony-Anhalt, the sites were located on flood plains of wide rivers that supported relict landscape and thus wild apple. The samples in Saxony-Anhalt were obtained from the Middle Elbe Biosphere Reserve which comprises the largest area of interconnected flood plains in Central Europe (BRÄUER und KrummhaAR, 2004). The Biosphere Reserve was considered to have the greatest local occurrence of M. sylvestris in Germany, amounting to more than 1162 trees. The 'Bahrebach' Valley in Saxony, in the lower

Table 1. - Description of the wild and cultivated apples analysed. For M. sylvestris the name of local origin, code, UTM data, number of individuals investigated, a brief outline of the original sampling location and provider of the plant material are given. For $M$. $\times$ domestica the time of breeding in three categories, code $M d$ or $d$, number of individuals investigated and provider of the plant material are given. Old or traditional German cultivars originated before 1900. Modern or new cultivars have been released since 1970. Cultivars whose origin is not precisely provided and who are supposed to originate between old and modern ones, build the middle-age group.

\begin{tabular}{|c|c|c|c|c|c|}
\hline $\begin{array}{l}\text { Species/ } \\
\text { Origin (location, time) }\end{array}$ & Code & Coordinates & $\mathrm{N}$ & Natural occurrence & Provider \\
\hline Malus sylvestris & $M s / s$ & & 477 & & \\
\hline Rhineland-Palatinate & $\mathrm{RP}$ & $49^{\circ} 10^{\prime} / 8^{\circ} 21^{\prime}$ & 86 & $\begin{array}{l}\text { Flood plains of the Rhine River; relict site for } M s \text { near } \\
\text { Germersheim/Hördt }\end{array}$ & FAWF RP* \\
\hline Saxony-Anhalt & ST & $51^{\circ} 50^{\prime} / 12^{\circ} 19^{\prime}$ & 124 & $\begin{array}{l}\text { Flood plains of the Elbe River; relict site for } M s \text {, } \\
\text { Middle Elbe Biosphere Reserve near Dessau }\end{array}$ & FÖLV BR 'Mittelelbe' \\
\hline Saxony & SN & $50^{\circ} 50^{\prime} / 13^{\circ} 54^{\prime}$ & 108 & $\begin{array}{l}\text { 'Bahrebach' Valley, lower eastern Ore Mountains; } \\
\text { valley with rich structuring at landscape level, e.g. } \\
\text { meadow, forest and edge habitat }\end{array}$ & Binder** \\
\hline North Rhine-Westphalia & NW & $50^{\circ} 35$ & 100 & Forests and edge habitats & LÖBF NW, Forest Gene Bank* \\
\hline Luxembourg & & $49^{\circ} 40^{\prime} / 6^{\circ} 22^{\prime}$ & 59 & Forests and edge habitats; main area at Grevenmacher & Forest Administration of $\mathrm{L}$ \\
\hline $\begin{array}{l}\text { Malus } \times \text { domestica } \\
\text { Old cultivars }\end{array}$ & $M d / d$ & & $\begin{array}{l}406 \\
223\end{array}$ & - & $\begin{array}{l}\text { Nursery ‘Old Cultivars' in SH, } \\
\text { FÖLV orchard 'Griesen' in ST, } \\
\text { FÖG, Kaiserslautern in RP; }\end{array}$ \\
\hline Middle-age cultivars & & & 60 & - & Fruit Gene Bank (until 2002) and \\
\hline Modern cultivars & & & 123 & - & BSA Testing Station Wurzen i. SN \\
\hline \multicolumn{6}{|c|}{$\begin{array}{l}\text { Notes: } \\
\text { - Coordinates refer to the main area of origin. } \\
\text { - Plant material was provided * from clonal seed orchards corresponding to trees in situ } * * \text { with the diploma thesis from BINDER } \\
\text { ( } 2010 \text { ). } \\
\text { - Putative wild apples (all genotypes sampled in the wild as representing } M s \text { ): pure wild individuals (qd }=0-0.2 \text { ), hybrids with cul- } \\
\text { tivars (qd }=0.201-0.799 \text { ), feral cultivars ( } q d=0.8-1.0 \text { ) in the culture group (see Table } 2 \text { ); admixed individuals/group (qd }>0.2 \text { ). It } \\
\text { is supposed that many individuals in the culture group are feral } M d \text { misclassified in the field. We cannot exclude introgressed } \\
M s \text { also belonging to that group. The assignment coefficient } q d \text { used in the definitions above is explained in the beginning of } \\
\text { 'results'. }\end{array}$} \\
\hline
\end{tabular}


eastern Ore Mountains, is a valley with rich structural diversity in the landscape showing meadows, forests and edge habitats. Saxony may be the only site at which all individuals were captured during sampling, forming a complete sample. The apple trees from North RhineWestphalia and Luxembourg grew in forests and forest edge habitats.

Distance between locations was several hundred kilometres except between the closest regions Luxembourg and Rhineland-Palatinate, where the distance was only approx. 160 kilometres. Mainly adult trees were selected for this study. Details concerning the apple trees at particular site are given in Table 1.

A total of 406 cultivars, separated into old, middleaged and modern categories, were provided by the 'Old Cultivars' Nursery in Sörup, in Schleswig-Holstein, the Fruit Gene Bank in Dresden-Pillnitz, Saxony (until 2002), and the Federal Plant Variety Office, Testing Station in Wurzen, Saxony. A few cultivars were obtained from two Promotion Societies (Table 1). Different subsets of cultivars were chosen according to their period of origin with the expectation that those cultivated in Germany for a long time were more likely to show genetic admixture with wild genotypes than others. The cultivars Jonathan, Jonagold, Fuji, Idared and Empire were used as standard genotypes in the isozyme study to improve comparison of results between gels.

\section{Isozyme analyses}

Twigs with winter buds were forced to flush under greenhouse conditions, and leaf samples were collected shortly after bud break in spring. For the analyses, about $1 \mathrm{~cm}^{2}$ of young fresh leaf tissue was crushed thoroughly in $0.3 \mathrm{ml}$ of either $0.1 \mathrm{M}$ Tris maleate $\mathrm{pH} 7.4$ containing $20 \%$ glycerol (w/v), $10 \%$ soluble polyvinylpyrrolidone (PVP-40) and $25 \%$ Triton X-100, or $0.05 \mathrm{M}$ potassium phosphate $\mathrm{pH}$ 7.0. Both extraction buffers contained $14 \mathrm{mM}$ 2-mercaptoethanol. Horizontal starch gel electrophoresis was conducted according to WEEDEN (1984). Protocols described in CHEvREAU and LAURENS (1987) and in MANGANARIS and Alston (1987) were partially adopted. Two buffer systems were used for electrophoresis. Slices from the Tris citrate/lithium borate $(\mathrm{pH} 8.4)$ gel were assayed for aspartate aminotransferase (AAT, EC 2.6.1.1, 2 loci with either 4 alleles) and triose phosphate isomerase (TPI, EC 5.3.1.1, 1 locus with 3 alleles). Slices from the histidine buffer ( $\mathrm{pH}$ 6.5) gel were assayed for diaphorase (DIA, EC 1.6.4.3, 2 loci with either 2 alleles), 6-phosphogluconate dehydrogenase (6PGDH, EC 1.1.1.44, 1 locus with 5 alleles), phosphoglucomutase (PGM, EC 2.7.5.1, locus -1 with 5 alleles, locus -5 with 2 alleles), malate dehydrogenase ( $\mathrm{MDH}$, EC 1.1.1.37, 1 locus with 2 allelels) and isocitrate dehydrogenase (IDH, EC 1.1.1.42, 1 locus with 2 alleles). Assay conditions and the interpretation of patterns have been described by WEEDEN and LAMB (1985 and 1987) as well as WENDEL and WEEDEN (1989). All accessions of $M$. sylvestris and $M . \times$ domestica were typed for 10 isozyme loci, spread over different chromosomes: TPI-5, AAT-1, AAT-2, PGM-1, PGM-5, DIA-2, DIA-4, 6PGDH-1, MDH4 , IDH-1. Loci were chosen based on degree of polymorphism and applicability to different Malus species.

\section{Morphological measurements}

The two most prominent morphological characters, the pubescence of leaf abaxial surface and fruit diameter both in autumn (WAGNER, 1996), were obtained, if available, to describe each wild apple tree from each site. Data were obtained from surveys conducted in different years by the providers of the plant material. Leaf pubescence was scored on a scale of 0 to 3 according to REMMY and GRUBER (1993) (0: hairless; 1: sparsely hairy (magnifier needed), hairs restricted to main nerves; 2 : moderately hairy, easily recognizable hairs on the entire leaf surface; 3: felted). A complex morphological description useful in part for comparison purposes existed for only one location. In that study a total of 35 characters had been measured and data further used in cluster and discriminate analyses to differentiate groups (BINDER, 2010).

\section{Statistical analyses}

A model-based Bayesian clustering approach (PRITCHARD et al., 2000) was applied to the multilocus genotype data using the computer program STRUCTURE. The method, which uses Markov Chain Monte Carlo algorithms, attempts to infer population structure and assign individuals to populations. Individuals are assigned probabilistically to an inferred number of clusters, and simultaneously the unknown allele frequencies within the subpopulations are estimated. These calculations are performed by obtaining Hardy-Weinberg structure and linkage equilibrium within the inferred subgroups. The proportional assignment of an individual to each cluster, $k=1 \ldots K$, is given by the estimates $q_{k}$. Assigning individuals jointly to two, or more clusters if their genotypes indicate admixture, allows the identification of putative hybrids. The method can be applied to various types of markers (e.g., isozymes, microsatellites, restriction fragment length polymorphism, or single nucleotide polymorphism) and can be highly accurate for a modest number of loci (PRITCHARD et al., 2000; VEKEMANS, pers. comm.). Five independent analyses were carried out for each number of clusters $K(1 \leq K \leq 7)$ with 50000 burn-in steps and MCMC iterations each. The most relevant number of clusters $(\mathrm{K})$ was determined using the $\Delta \mathrm{K}$ statistic (EvANNo et al., 2005). To handle existing linkage groups relevant in this study, STRUCTURE with 'linkage model' was applied. This model is essentially a generalization of the admixture model, which is able to deal with admixture linkage disequilibrium. Map distances of the TPI-5:PGM-1, and the AAT1:IDH-1 linkage were provided by MALIEPAARD et al. (1998) and WEEDEN (pers. comm.). The appropriate software STRUCTURE 2.2 (PRITCHARD et al., 2007) was used.

After the exclusion of hybrids and feral cultivars within the putative wild apples, genetic structure was determined for $M$. sylvestris originating from 5 of the locations investigated. Calculations were performed on the basis of the allele frequencies of ten polymorphic loci using the program GSED (GILLET, 2010). Measures of genetic variation within (e.g. allelic and genotypic richness) and between (e.g. gene pool distance, subpopula- 
tion differentiation) samples, heterozygosity and fixation coefficient are described in detail in HATTEMER et al. (1993) and in the GSED user's manual (http://www.unigoettingen.de/de/95607.html).

\section{Results}

Gene pools in the Malus sample and individuals of hybrid character in putative M. sylvestris

To infer population structure and the corresponding number of gene pools from nuclear gene data, all individuals were included in the statistical analysis. Based on the likelihood output of the genetic admixture analysis using no prior information on sample origin $(\Delta \mathrm{K}=$ 125.1, $\operatorname{Pr} \mid \ln L=-11565.6$ ), and based on biological plausibility, the distribution of individuals was best described by two clusters. The summary results (Table 2 , left) showed that representatives of $M$. sylvestris and those of $M . \times$ domestica could clearly be grouped into two different gene pools, putative wild apples into gene pool 1 and definite cultivated apples into gene pool 2 .

Different proportions of admixture were apparent. Over all $M$. sylvestris samples, an admixture with $M$. $\times$ domestica of 0.138 was found. For only the wild apples growing in Germany, a slightly lower admixture with cultivated apples $(0.111)$ was observed. The proportion of genetic information assigned to the domestic gene pool ranged from 0.044 in Rhineland-Palatinate to 0.163 in North Rhine-Westphalia. Of the wild apples originating from Luxembourg, at most 0.245 was admixed.

Old cultivars showed slightly more admixture with wild apples (0.099) than more recent cultivars (about $0.06)$.

To be able to make a decision about the hybrid status on the individual level the following procedure was applied. For individual trees in the total sample, the proportions of assignment to the inferred $M . \times$ domesti$c a$ gene pool ( $q d$ ) were arranged in ascending order (Figure 1). In addition, certain cut-off values were chosen. This choice was made arbitrarily using the $20 \%$ mark at each end of the curves shown in Figure 1. Genotypes collected as $M$. sylvestris in the wild that were assigned for more than $20 \%$ and less than $80 \%$ to gene pool $2(\mathbf{M} d)$ were considered hybrids. Those with more than $80 \%$, inclusive, assigned to gene pool $2(\mathrm{M} d)$ were considered feral cultivars (according to COART et al., 2006). By adopting this approach, the intermediate hybrid zone could be studied, and the presence of both hybrids and cultivars among the individuals sampled as wild apple revealed. Within the total putative M. sylvestris sample, 82 trees $(17.2 \%)$ were identified as not pure wild but as hybrids ( 66 trees, $13.8 \%$ ) or as feral cultivars (16 trees, $3.4 \%$ ). Within the German putative M. sylvestris sample, 65 trees $(15.6 \%)$ were identified as not pure wild but as hybrids (58 trees, $13.9 \%$ ) or as feral cultivars (7 trees, $1.7 \%$ ). A detailed overview of the different locations is given in Table 2 (right). The sum of the values for hybrids and feral cultivars $(\mathrm{H}+\mathrm{C})$ differed from $2.3 \%$ in Rhineland-Palatinate to $28.8 \%$ in Luxembourg. Hybrids were a major component whereas feral cultivars were less prevalent. Luxembourg proved an exception; there the opposite was found. About $15 \%$ of the trees in that sample (L) were identified as cultivars living in the wild.

\section{Verification of genetic results by morphological traits Fruit size}

In Table 3 results of fruit size were summarized for three genetically defined groups in four M. sylvestris sampling locations. North Rhine-Westphalia was exclud-

Table 2. - Left: Summary of the results of a model-based cluster analysis for multilocus genotype data (Software STRUCTURE with ,linkage model'). The proportions of assignment to each of two inferred gene pools estimated for genotypes of a given category of origin are listed.

Right: Summary of single tree assignment of putative wild apples in Germany and in Luxembourg by using a $20 \%$ cut-off value for $\mathrm{q}$. The assignment of individual genotypes into the pure wild group (Wild, $\mathrm{q} d=0-0.2$ ), intermediate hybrid group $(\mathrm{H})$ and culture group (C) supposed to contain feral cultivars ( $q d=0.8-1$ ) is shown. Results are given as percentage of trees.

\begin{tabular}{|c|c|c|c|c|c|c|}
\hline Category of origin & $\begin{array}{l}\text { Gene pool } 1 \\
\text { M. sylvestris }\end{array}$ & $\begin{array}{c}\text { Gene pool } 2 \\
M . \times \text { domestica }\end{array}$ & Wild & Hybrid & $\begin{array}{l}\text { Culture } \\
\%\end{array}$ & $\mathrm{H}+\mathrm{C}$ \\
\hline Ms Rhineland-Palatinate & 0.956 & 0.044 & 97.7 & 2.3 & 0 & 2.3 \\
\hline Ms Saxony-Anhalt & 0.910 & 0.090 & 87.9 & 11.3 & 0.8 & 12.1 \\
\hline Ms Saxony & 0.852 & 0.148 & 78.7 & 19.4 & 1.9 & 21.3 \\
\hline Ms North Rhine-Westphalia & 0.837 & 0.163 & 75.0 & 21.0 & 4.0 & 25.0 \\
\hline Ms Luxembourg & 0.755 & 0.245 & 71.2 & 13.5 & 15.3 & 28.8 \\
\hline$M s$ Total & 0.862 & 0.138 & 82.8 & 13.8 & 3.4 & 17.2 \\
\hline$M s$ Total $_{\text {Germany }}$ & 0.889 & 0.111 & 84.4 & 13.9 & 1.7 & 15.6 \\
\hline Md Old cultivars & 0.099 & 0.901 & & & & \\
\hline Md Middle age cultivars & 0.062 & 0.938 & & & & \\
\hline$M d$ New cultivars & 0.059 & 0.941 & & & & \\
\hline Md Total & 0.073 & 0.927 & & & & \\
\hline
\end{tabular}




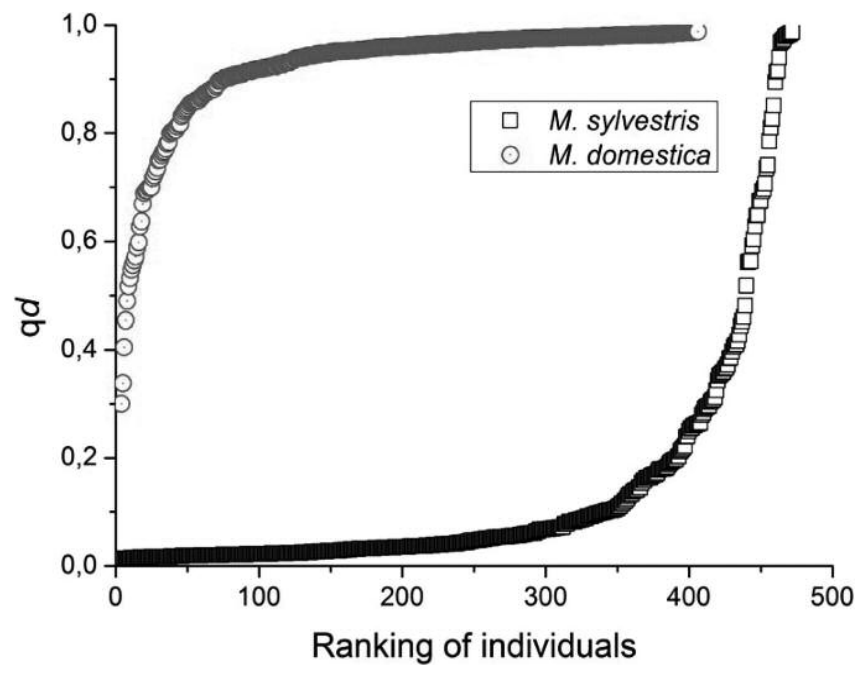

Figure 1. - The probabilistic assignment of individuals to the inferred domestica cluster based on $q d(0-1)$ arranged in ascending order. The affinity to cultivation increases from left to right. ed because the fruit had been sampled non-systematically. First the quantitative data for fruit size in the pure wild group were compared among the different locations. Mean fruit diameter of pure apples differed from $29.1 \mathrm{~mm}$ in Saxony-Anhalt to $33.8 \mathrm{~mm}$ in Saxony. On average a maximum difference of $4.7 \mathrm{~mm}$ was found among the sites. Rhineland-Palatinate and Luxembourg had identical mean values of $31.2 \mathrm{~mm}$. Coefficients of variance (CV) varied between $10 \%$ (ST: SD is 2.9) and $17 \%$ (L: SD is 5.4). While the range in minimum values was very small, from $21 \mathrm{~mm}(\mathrm{RP})$ to $24 \mathrm{~mm}(\mathrm{ST})$, variability in maximum values among the sites was larger ranging from $37.6 \mathrm{~mm}$ (ST) up to $47.8 \mathrm{~mm}(\mathrm{SN})$. The mean diameter of all fruiting pure apples, 226 trees in total, was $31.2 \mathrm{~mm}$. The corresponding coefficient of variance was $14.7 \%$.

The second point of interest was fruit size of both the hybrid and the culture group (Table 3). The hybrid group differed only slightly from the pure wild group. Mean fruit diameters of the hybrids were only slightly

Table 3. - Fruit size of apple trees collected in the wild in the defined genetic groups (see Table 2, right). For each sample location and for the total sample, the mean value of fruit width (mm) is listed along with standard deviation (SD), minimum (Min) and maximum (Max). Low-level values indicate the number of individuals bearing fruit.

\begin{tabular}{|l|llll|lllll|lll|l|}
\hline \multirow{2}{*}{ Location } & \multicolumn{6}{|c|}{ Wild Group (qd: 0-0.2) } & \multicolumn{4}{|c|}{ Hybrid Group } & \multicolumn{4}{c|}{ Culture Group (qd: 0.8-1) } \\
& Mean & SD & Min & Max & Mean & SD & Min & Max & Mean & SD & Min & Max \\
\hline $\mathrm{RP}_{(63)}$ & $31.2_{(61)}$ & 4.3 & 21.0 & 45.0 & $35_{(02)}$ & 2.1 & 30.0 & 33.0 & - & & & \\
$\mathrm{ST}_{(93)}$ & $29.1_{(83)}$ & 2.9 & 24.0 & 37.6 & $31.2_{(09)}$ & 4.7 & 25.7 & 40.9 & $36.5_{(01)}$ & - & - & - \\
$\mathrm{SN}_{(88)}$ & $33.8_{(70)}$ & 5.0 & 22.2 & 47.8 & $34.4_{(17)}$ & 7.3 & 20.6 & 45.8 & $28.1_{(01)}$ & - & - & - \\
$\mathrm{L}_{(23)}$ & $31.2_{(12)}$ & 5.4 & 23.1 & 37.9 & $31.9_{(05)}$ & 6.3 & 25.1 & 40.5 & $45.4_{(06)}$ & 10.2 & 30.0 & 55.5 \\
\hline Total $_{(267)}$ & $31.2_{(226)}$ & 4.6 & 21.0 & 47.8 & $33.0_{(33)}$ & 6.3 & 20.6 & 45.5 & $42.1_{(08)}$ & 10.7 & 28.1 & 55.5 \\
\hline
\end{tabular}

Note: The meaning of 'Wild' Group in table is 'Pure Wild' Group.

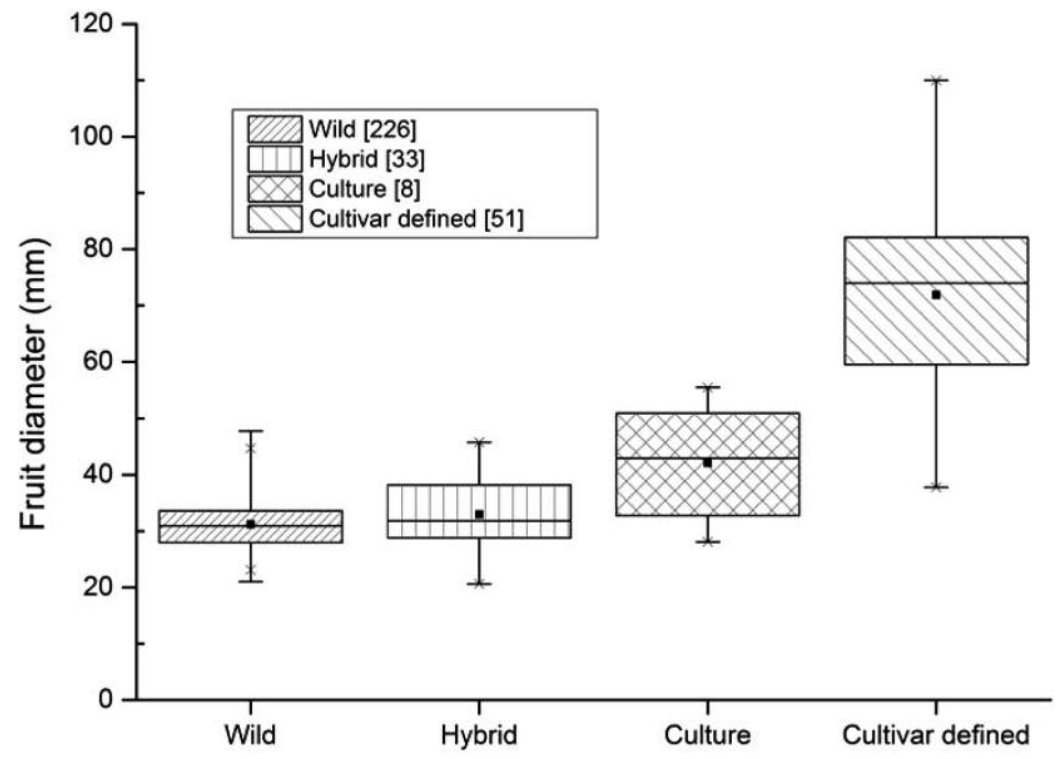

Figure 2. - Fruit diameter of apple trees. Boxplots represent three genetic groups of M. sylvestris sampled in the field (pure wild, hybrid, culture groups) along with one group of $M$. $\times$ domestica constituting defined cultivars for reference. Mean value is illustrated by black dots, and median is shown by square lines in boxes. Number of individuals is given in brackets.

Note: The meaning of 'Wild' in figure is 'Pure Wild'. 
larger at each site. In total, there was a difference of $1.8 \mathrm{~mm}$ between the two groups. The fruit of the few individuals constituting the culture group were almost $1 \mathrm{~cm}$ larger than hybrid fruit. Figure 2 illustrates the relative position of the groups constituting of apples growing in the field compared to a reference group of defined cultivars. A major change in fruit size between the hybrid and culture group was evident, but the most important change occurred between the $M s$ culture group and the $M d$ cultivar group, where the latter had fruit $71.9 \mathrm{~mm}$ in diameter on average (SD $14.3 \mathrm{~mm}, \mathrm{CV}$ $20 \%$, minimum $37.8 \mathrm{~mm}$, maximum $110 \mathrm{~mm}$ ). Smallest variation (smallest box) was recognized within the pure wild group. Variation increased in the hybrid and culture boxes along with decreasing sample size. Greatest variation was found in the cultivar box.

Shapiro-Wilk normality test rejected null hypothesis of normal distribution at p-value 0.000. A Kruskal-Wallis rank sum test was performed to identify differences between the three genetically based groups, i.e. pure
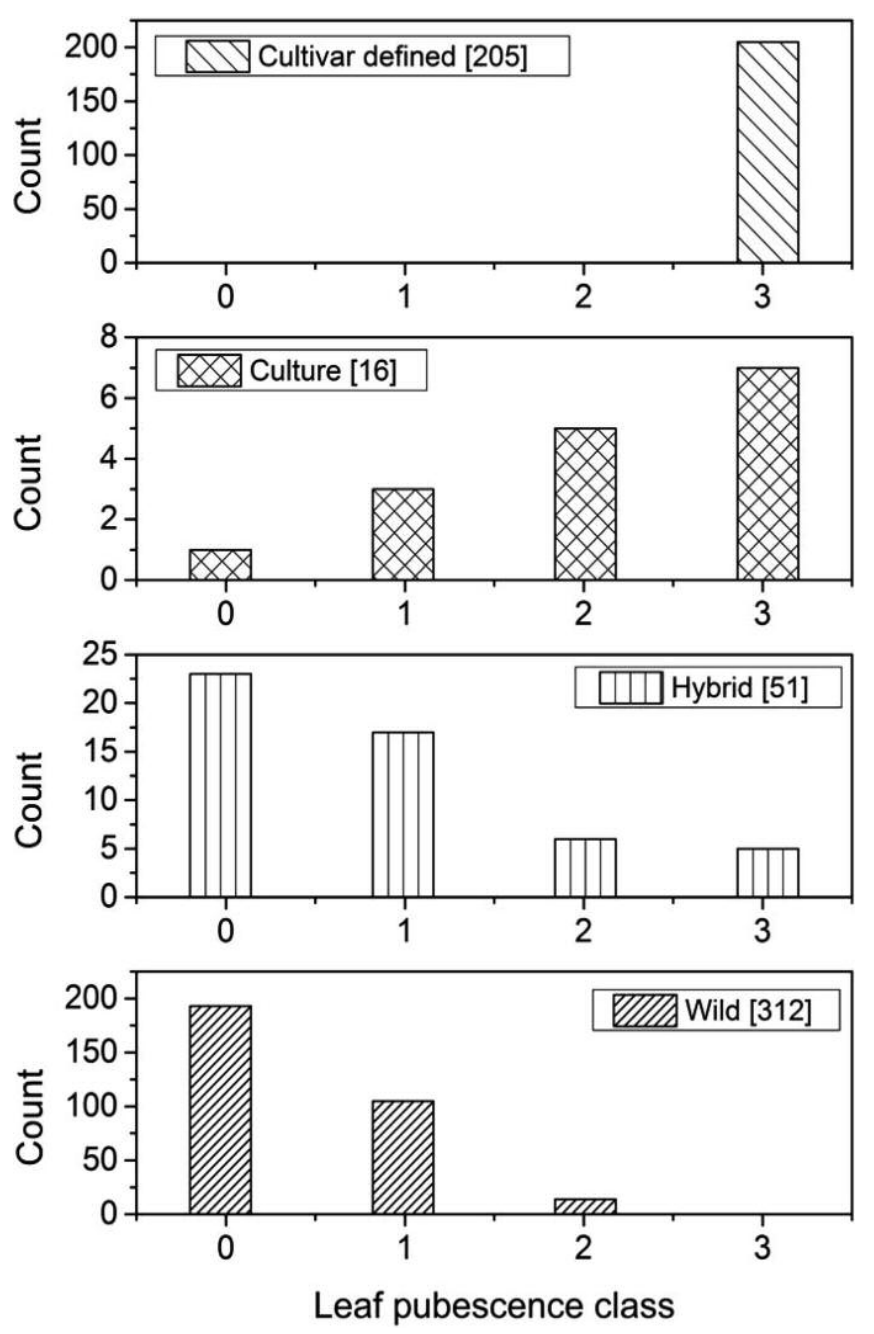

Figure 3. - Leaf pubescence of apple trees. Histograms represent three genetic groups of $M$. sylvestris sampled in the field (pure wild, hybrid, culture groups) along with one group of $M$. $\times$ domestica constituting defined cultivars for reference. Number of individuals is given in brackets.

Note: The meaning of 'Wild' in figure is 'Pure Wild'. wild, hybrid and culture groups $(\mathrm{p}=0.0074)$. Pairwise Wilcox rank sum test ( $\mathrm{p}$ value adjustment method Bonferroni) yielded significant differences only between the pure wild and culture groups $(p=0.012)$, whereas the hybrid and culture groups $(\mathrm{p}=0.083)$ and pure wild and hybrid groups $(\mathrm{p}=0.517)$ were not significantly different.

To deal with outliers or right-skewed distribution within the pure group, $95 \%$ of the individuals were chosen in ascending order of fruit diameters. After eliminating the greatest extremes, the remaining pure wild group comprised fruit varying from 21 to $39.5 \mathrm{~mm}$ in diameter. By comparison, the remaining hybrid group treated in the same way comprised fruit with diameters ranging from 20.6 to $41.7 \mathrm{~mm}$.

\section{Leaf pubescence}

The pubescence of leaves was assessed into 4 classes by visual ratings. Therefore results were less differentiated. Median values in the pure wild, hybrid and culture groups for the five sites were as follow: RP $(00-)$, ST $(0$ 0 2), SN ( $\left.\begin{array}{lll}0 & 0 & 1\end{array}\right)$, NW ( $\left.\begin{array}{lll}1 & 1 & 2\end{array}\right)$ and L ( $\left.\begin{array}{lll}1 & 1 & 3\end{array}\right)$. Largest differences among the sites were observed in the culture group with values ranging from 1 in $\mathrm{SN}$ to 3 in L.

Medians over all samples in each of the four groups, pure wild, hybrid, culture and cultivar, increased from 0 in the pure wild to 3 in the cultivar group in ascending order. Histograms in Figure 3 look quite different. There was no variation in the $M d$ cultivar group. In the pure wild group, there was no leaf pubescence class ' 3 '. Kruskal-Wallis rank sum test analysed differences between the genetically-differentiated-, i.e. pure wild, hybrid and culture groups $(\mathrm{p}=0.000)$. Pairwise Wilcox rank sum test ( $p$ value adjustment method Bonferroni) yielded significant differences between all pairs; pure wild and hybrid group ( $\mathrm{p}=0.00726$ ), pure wild and culture group $(\mathrm{p}=0.0)$ and hybrid and culture group $(p=0.00033)$. Despite significant differences between group pairs the distributions overlapped.

Choosing $95 \%$ of individuals based on increasing values (see procedure for fruit size), pubescence in the pure group varied from 0 to 1 and pubescence in the hybrid group varied from 0 to 3 .

\section{Complex morphological characteristics}

Saxony is the only location where apple trees had already been described and many morphological characters analysed. In total, 35 different traits were used in cluster analysis simultaneously to obtain a complex morphological description of individuals (BINDER et al., 2011). In this specific analysis, all characters visible in one year had been included. Thus, seventy (one clonal identity excluded) putative wild apples growing in the 'Bahrebach' Valley have been extensively characterized. Based on the complex morphological classification, 57 trees $(81.4 \%)$ were classified as pure wilds and 13 trees (18.6\%) were classified as hybrids (see BINDER, 2010).

Within the morphological pure wild cluster, 53 individuals were also assigned to the pure wild group based on their genetic character $(\mathrm{q} d)$. This showed concordance between the complex morphological and the com- 
Table 4. - Genetic variation within samples after exclusion of hybrids and feral cultivars. For each location, the number of pure individuals is given. Results are listed for percentage of polymorphic loci ( $\mathrm{P}, 0.95$ criterion), mean number of alleles per locus $(\mathrm{A} / \mathrm{L})$, mean number of genotypes per locus $(\mathrm{G} / \mathrm{L})$, diversity of the gene pool $\left(\mathrm{v}_{\text {pool }}\right)$, diversity of the hypothetical gametic multilocus $\left(\mathrm{v}_{\text {gam }}\right)$, actual or observed heterozygosity $\left(\mathrm{H}_{\mathrm{a} / \mathrm{o}}\right)$, total differentiation of the gene pool $\left(\delta_{\mathrm{T}}^{\mathrm{gam}}\right)$ and fixation coefficient $(\mathrm{F})$. Arithmetic means over all populations/collections are calculated for pure wild apple with $\left(_{\text {all }}\right)$ and without $\left(_{G}\right.$ ) Luxembourg (L) along with standard deviation (SD) and coefficient of variance (CV). Measures of genetic variation also are listed at the species level.

\begin{tabular}{|c|c|c|c|c|c|c|c|c|c|}
\hline Location & $\mathrm{N}$ & $\mathrm{P}$ & $\mathrm{A} / \mathrm{L}$ & $\mathrm{G} / \mathrm{L}$ & $\mathrm{V}_{\text {pool }}$ & $\mathrm{V}_{\text {gam }}$ & $\mathrm{H}_{\mathrm{a}}=\mathrm{H}_{\mathrm{o}}$ & $\delta_{\mathrm{T}}$ & $\mathrm{F}$ \\
\hline $\mathrm{RP}$ & 84 & 90 & 2.6 & 3.9 & 1.535 & 104 & 0.319 & 0.350 & 0.089 \\
\hline L & 42 & 100 & 2.4 & 3.3 & 1.582 & 126 & 0.362 & 0.372 & 0.027 \\
\hline ST & 109 & 80 & 2.7 & 4.3 & 1.555 & 139 & 0.350 & 0.358 & 0.022 \\
\hline NW & 75 & 100 & 2.9 & 4.3 & 1.592 & 145 & 0.335 & 0.374 & 0.104 \\
\hline SN & 85 & 80 & 2.8 & 4.1 & 1.523 & 122 & 0.353 & 0.345 & -0.023 \\
\hline Mean $_{\text {all }}$ & - & 90 & 2.68 & 3.98 & 1.557 & 127.20 & 0.344 & 0.360 & 0.044 \\
\hline SD & - & 10 & 0.192 & 0.415 & 0.030 & 15.99 & 0.017 & 0.013 & 0.052 \\
\hline $\mathrm{CV}$ & - & 0.11 & 0.072 & 0.104 & 0.019 & 0.13 & 0.049 & 0.036 & \\
\hline Mean & - & 87.50 & 2.75 & 4.15 & 1.551 & 128 & 0.339 & 0.357 & 0.048 \\
\hline Species & 395 & 90 & 3.10 & 5.20 & 1.583 & 152 & 0.342 & 0.369 & \\
\hline
\end{tabular}

Note: Total differentiation of the gene pool $\left(\delta_{\mathrm{T}}\right.$; GREGoriUs, 1987) is like expected heterozygosity ( $\mathrm{H}_{\mathrm{e}}$; BERG and HAMRICK, 1997) (FINKELDEY und BONFILS, 2001).

plex genetic classification of $93 \%$. Within the morphological hybrid cluster, 7 individuals were also assigned genetically into the hybrid group. Here concordance was $54 \%$. Conversely, the correspondence between complex genetic and complex morphological classification was $90 \%$ within the pure wild and $64 \%$ within the hybrid group.

\section{Genetic variation and differentiation in wild apple trees after exclusion of recent hybrids and feral cultivars}

After exclusion of first-generation hybrids and feral cultivars, genetic structure of pure wild apples was determined separately for the local samples. All gene loci of the enzyme systems analysed were polymorphic for M. sylvestris. Most loci investigated had more than one allele with a frequency clearly exceeding $5 \%$, indicating major polymorphism. In this study, six alleles were found to be private to the wild species, one of them occurring only once in Saxony-Anhalt and another once in North Rhine-Westphalia. Three of the private alleles were restricted to single locations.

The tests of homogeneity of the genetic structures were significant $(\mathrm{P}<0.05)$. Overall, a good fit to HardyWeinberg expectations was found confirming the existence of effective outcrossing. Diversity statistics are summarized in Table 4 . The mean number of alleles per locus $(\mathrm{A} / \mathrm{L})$ varied from $2.4(\mathrm{~L})$ to $2.9(\mathrm{NW})$, the respective number of genotypes $(\mathrm{G} / \mathrm{L})$ from $3.3(\mathrm{~L})$ to 4.3 (ST and NW). Minima were expected due to the low sample size of the corresponding location (L). Gene pool, and hypothetical gametic diversity were 1.557 , and 127.2 on average over all five sites respectively. The diversity of the gene pool was high, with the highest diversity in NW with 1.592 and in L with 1.582. Measures of observed and expected heterozygosity were also high, with mean values of 0.344 for $\mathrm{H}_{\mathrm{o}}$ and 0.360 for $\mathrm{H}_{\mathrm{e}}$. The total differentiation of the gene pool was highest and nearly equal in NW and L. Very similar levels of genetic variation were found in all samples as indicated by the coefficients of variance (CV). These coefficients were very low, e.g. only $1.9 \%$ for gene pool diversity, $3.6 \%$ for total differentiation and $7.2 \%$ for number of alleles per locus. The average fixation coefficient $(F)$ for all pure wild samples was 0.044 and low. Fixation coefficients were slightly to moderately positive in four sites. In population $\mathrm{SN}$, a slight excess of heterozygote genotypes was detected. The mean values calculated for locations in Germany revealed only very slight differences compared to the overall means.

Differentiation measures were summarized in Table 5. The lowest and closest genetic distance $\left(\mathrm{d}_{0}\right)$ of 0.065 was found between ST and SN. At 0.083 the distance between RP and L also was relatively low. Highest genetic distance of 0.148 was observed between RP and ST. Four values of $d_{0}$ were very similar, and ranged from 0.130 to 0.135 . Delta $(\delta)$ of the subpopulation differentiation $\left(\mathrm{d}_{\mathrm{j}}\right)$ was 0.089 , separating $\mathrm{RP}$ and $\mathrm{L}$ from

Table 5. - Genetic variation between samples after exclusion of hybrids and feral cultivars. Pairwise comparison between populations or collections is shown by gene pool distance $\left(\mathrm{d}_{0}\right)$ (upper Table). Weighted subpopulation differentiation $\left(\mathrm{d}_{\mathrm{j}}\right)$ of samples and delta $(\delta)$ of the gene pool is also given (bottom line)

\begin{tabular}{lllllll}
\hline & & RP & L & ST & NW & SN \\
\hline & RP & & & & & \\
& L & 0.083 & & & & \\
$\mathrm{~d}_{0}$ & ST & 0.148 & 0.132 & & & \\
& NW & 0.135 & 0.093 & 0.081 & & \\
& SN & 0.131 & 0.130 & 0.065 & 0.107 & \\
\hline $\mathrm{d}_{j}$ & $\delta=0.089$ & 0.115 & 0.092 & 0.085 & 0.080 & 0.074 \\
\hline
\end{tabular}


Table 6. - Frequencies (\%) of alleles specific to $M$. sylvestris are listed for five locations; hybrids and ferals have been excluded. Private alleles with frequencies $>2 \%$ are shown only.

\begin{tabular}{lccccc}
\hline $\begin{array}{l}\text { Location } \\
M s-A l l e l e\end{array}$ & RP & L & ST & NW & SN \\
\hline PGM-1'e' & 0 & 0 & 2.3 & 0 & 8.2 \\
TPI-5'c' & 21.4 & 20.2 & 15.1 & 12.7 & 17.1 \\
DIA-4'a' & 56.5 & 58.3 & 43.6 & 52.7 & 41.8 \\
PGM-1'c' & 83.9 & 86.9 & 51.8 & 64.7 & 54.1 \\
\hline
\end{tabular}

the other three locations that were lower that mean. Subpopulations with a low $\mathrm{d}_{\mathrm{j}}$ represented the total very well. RP attracted attention revealing the highest differentiation $\left(d_{j}=0.115\right)$ to the remaining sample (complement). Alleles specific to $M s$ appearing more than once did reflect the differentiation among the samples to a certain extent (Table 6; for species-specific alleles in $M s$ and $M d$ see WAGNER et al., 2004 and WAGNER, 2011). PGM-1'e' only appeared in ST and SN. The frequencies of the other three private alleles TPI-5'c', DIA-4'a' and PGM-1'c' were close and higher for the group RP-L, and close and lower for the group ST-SN. The sample NW did not fit clearly to either the one or the other group based on genetic differentiation.

\section{Discussion}

Gene pools of Ms and Md and individuals identified as hybrid and feral cultivar

A model-based cluster analysis of all isozyme data from 883 apple genotypes showed that wild and cultivated apple trees currently make up two distinct gene pools that can be discriminated clearly by nuclear markers. No complete admixture between wild living apples and domesticated apples has occurred in the past although it might have been expected. In spite of extensive domestication of apples over a long time, wild genotypes have not lost their genetic identity through hybridization with cultivated genotypes in the natural distribution area of $M$. sylvestris studied. This result strongly confirmed former results by COART et al. (2003) and LARSEN et al. (2006) based on small/smaller sample sizes of Malus as well as results based on a large sample set of apple trees (COART et al., 2006). The probabilistic assignment of individuals to the inferred domestica cluster using a reference of 406 cultivars in this study (Figure 1) appears very similar to the assignment by COART et al. (2006, see Fig. 2) using 422 representatives of $M$. × domestica for reference purposes. Independent of nuclear marker type (isozymes in this study and microsatellites in the other studies) and origin of putative wild apples in Europe (Germany, Luxembourg in this study, Belgium and Denmark in the other studies), conclusions alike about genetic differences between M. sylvestris and $M . \times$ domestica were drawn in this study. A wild gene pool distinct from the domestic gene pool is very encouraging to increasing conservation efforts in European countries.

Strong similarities between the different studies are also evident for assignments of the admixed apples. Within the different models applied in STRUCTURE, only $11.2 \%$ (Denmark: LARSEN et al., 2006; Belgium: COART et al., 2006) to $13.9 \%$ (Germany: this study, 'Total') of all putative $M$. sylvestris were identified as hybrids. Very few trees $(0 \%, 3.3 \%$, and $1.7 \%$ in Denmark, Belgium and Germany respectively) were identified as feral $M d$. In total $11.2 \%$ (Denmark), $14.5 \%$ (Belgium) and $15.6 \%$ (Germany) were not classified as pure wild individuals $(\mathrm{H}+\mathrm{C}$, see Table 2, right). In Luxembourg, a comparatively high number of feral cultivars $(15.3 \%)$ was calculated. In that case more misclassifications may have occurred in practice when cultivars were selected in the landscape, which might happen during selection in winter. Mean proportions of admixture in our study (0.111, German sample) are similar to those (0.119, Table 3) observed by CoRNILle et al. (2012).

Different levels of gene flow between a native and cultivated species were reported for the genus Populus (HeInZE, 1997; VANDEN BROECK et al., 2004). The risk of introgression depends on the surrounding trees and can be high as observed in black poplar and also in wild apple seed orchards (KLEINSCHMIT et al., 2012).

Differences in introgression from $M . \times$ domestica to $M$. sylvestris growing in four different states in Germany and in Luxembourg were evident. Percentage of hybrids ranged from nearly zero (RP) to $21 \%(\mathrm{NW})$ (see Table 2, right). This accord well with the result from four populations in Denmark $0 \%$ in KA, $3.6 \%$ in NO, $12 \%$ in $\mathrm{KO}$ and $26 \%$ in $\mathrm{HE}$, see LARSEN et al., 2006). From these findings one can conclude, that conservation strategies must be adapted to local situations. Such conservation measures at the local level may be more challenging at sites where the amount of first-generation hybrids and feral $M d$ trees is high.

It is not really surprising that wild apples tend to be genetically closer to old cultivars than to more recent cultivars. Representatives of $M . \times$ domestica cultivated for a long time in Germany and Luxembourg are expected to have been more involved in gene exchanges with native apples than recent cultivars.

Genetic barriers in general to interspecific hybridization within the subfamily Maloideae are described to be weak (KoRBAN, 1986). Indications of pre- and postzygotic barriers to hybridization between wild and cultivated apples could not be found (LARSEN et al., 2008). Even so, an extent of $11 \%$ to $14 \%$ of hybrids across several European countries occurs. Thus, there must be an effective barrier - not yet well observed or investigated - that hampers hybridization. Potential barriers to gene flow have been discussed extensively in former studies concerning wild apple. Two major mechanisms have been found to prevent or impede reproductive communication between $M$. sylvestris and $M$. × domestica; a distance and a time mechanism. Isolation by distance means geographical distance between trees of the two species which interferes with the pollinator behaviour. In all, the circle of pollinators is very diverse (KUGLER, 1970). Although honey and bumblebees, both major pollinators of apples, are able to travel several kilometres during their foraging flights (BEEKMAN and RATNIEKS, 2000; SteFFAN-DEWENTER and KuHN, 2003), events of long distance pollination might be important for evolution (ELL- 
STRAND, 2003). In current situations in natural populations, short distance pollination is most likely. Generally, insects will not move far if they have sufficient food resources in the vicinity. Various sources of pollen are accepted, pointing to the generalist behaviour of pollinators (CRESSWELL, 1997). Fondness for a specific pollen is also a known trait of pollinators; bees are crazy about dandelions and visit fruit tree flowers last pointing to some (food) competition and therefore to the risk of apple flowers not becoming pollinated "upstairs", e.g. in orchards (BÜTTNER, pers. comm.). Isolation by time or temporal isolation means the timing and duration of flowering differs between the two species, thus restricting seasonal overlap in reproduction periods. Both mechanisms of isolation have been thought to hinder hybridization primarily in populations in Denmark; e.g. only slight overlapping flowering periods, generally later flowering of cultivars (LARSEN et al., 2008) and pollination mostly within short distances of approx. $23 \mathrm{~m}$ (LARSEN and KJÆR, 2009) were observed. The latter observation was similar in a German offspring sample indicating a pollination distance mostly within $50 \mathrm{~m}$ (REIM et al., 2013). Later flowering of domestic trees was also observed in Belgium (COART et al., 2003). Differences in flowering phenology were also found to hinder hybridization among closely related Malus species in North America (DICKSON et al., 1991). However, variability in flowering period should be studied further, in particular in local cultivars used in Germany in the near neighbourhood of wild apples. Furthermore, in addition to fruit set, seed production, germination and early development of seedlings (see LARSEN et al., 2008), physiological studies should be performed to investigate the growth of hybrids in the wild, in particular up to their reproductive age. The fitness of a hybrid, and also of a cultivar, under natural conditions should be one important issue given the probability of hybridization in nature.

Former conclusions could be confirmed for European countries: hybridization between $M$. sylvestris and $M$. $\times$ domestica does occur in nature, is relatively moderate in extent (nuclear gene information) and both species still form distinct gene pools across Europe. However, investigation of chloroplast DNA points to a closer relationship between the two species than appreciated up to now (COART et al., 2006). Thus, more research on European native apples is needed to gain better insight into ancient hybridization.

\section{Morphological variability and correspondence between morphological and genetic traits}

Most research into the identification of $M$. sylvestris has focussed on morphology in the past. Much literature is available on the phenotypic traits of wild apples native to Europe (partially compiled in WAGNER, 1996). At least 45 characteristics have been described empirically. Up to now, only few quantitative studies on a limited numbers of individuals or characteristics exist. The present study facilitated the analysis of many apple trees for fruit size ( $M s: 267$ trees, $M d: 51$ trees), leaf pubescence (Ms: 379 trees, $M d: 205$ trees) and complex morphological characteristics (Ms: 70 trees). In the observation of single characteristics, the two most prominent morphological characters for discrimination specifically were chosen. In the observation of multiple characteristics, that is of complex morphological characteristics, the largest number of morphological characters so far has been analysed simultaneously. The natural (today) morphological variability and the correspondence between morphology and genetics are two important morphological aspects little studied so far. Both these aspects are of interest for conservation activities in practice, e.g. identification in the field, and decision about valuable objects for conservation programs.

There is considerable variation in the traits in the genetically determined groups, i.e. in the pure wild, hybrid and culture groups, as can be seen from, e.g., fruit size in the pure wild group (Table 3). While a fruit size of $35 \mathrm{~mm}$ is most often taken as a threshold for wild apples (taken from literature), the $95 \%$ interval of fruit diameters in this investigation was reached at $39.5 \mathrm{~mm}$. If we accept this $95 \%$ interval, we can conclude that pure $M$. sylvestris fruit ranges from 21 to $40 \mathrm{~mm}$ (approx.) in diameter. As far as we know, it is the first time that a lower limit of pure fruit size is defined. The intraspecific variability is similar to that for $M$. orientalis (20-30 mm, SCHMIDT, 2006), and much lower than that documented for other Malus species like M. sieversii (15-60 mm, FISCHER, 1995) and $M . \times$ domestica (40-110 mm, see Figure 2; approx. 30-120 mm, FiscHER, pers. comm.). $M$. sieversii expresses a particularly large variability in fruit characteristics (HoKANson et al., 1997).

Similar findings apply for the feature of hairiness (see Figure 3). Here, in the pure wild group, the $95 \%$ interval of pubescence is reached at a score of 1 . This corresponds to COART et al. (2003) who suggested “...that some genetic variation in the degree of hairiness exists within the wild populations." Autumn leaf hairiness of pure wilds appears to vary from score 0 to score 1 . However, no variation in hairiness is observed in defined cultivars. This finding is confirmed by SILBEREISEN (pers. comm.) who did not observe a single cultivar without felted hairy leaves at score 3. Furthermore, the frequency distribution of leaf pubescence scores shown in Figure 3 is similar for the pure wild and the hybrid groups with prevailing low hairiness scores and for feral and defined cultivar groups with prevailing high hairiness scores. Thus, the skewness of the frequency distributions changes between the hybrid group and the culture group. This is also true when only individuals of the hybrid group with $q d$ values larger than 0.6 are taken into consideration (results not shown).

The extent of variation within each group explains in part why no morphological trait can be regarded as distinct between the genetically defined groups (see Figures 2 and 3) and thus no single morphological trait of a specimen can be used to assign trees to groups in the field. To our best knowledge, individuals revealing leaf pubescence with a score of 2 or 3 are not pure wild. Observing those with scores 0 or 1 , one cannot be sure whether individuals are pure wild or hybrid. For fruit size, the extent of overlap of traits is even higher, proba- 
bly due to the very high variability in domestic fruit. However, even with the most complex morphological description available (BINDER et al., 2011), the correspondence between complex genetic and morphological determination methods does not exceed $93 \%$ in pure wilds and $64 \%$ in hybrids at the specimen level. Divergence of genetic and morphology on the individual level was also observed by LARSEN et al. (2006). Another comprehensive evaluation of morphological characters has been performed recently by REIM et al. (2012).

\section{Genetic variation and differentiation in pure wild apple trees}

This study may be one of the first studies reporting genetic data in $M$. sylvestris after the exclusion of firstgeneration hybrids and feral cultivars to improve population genetic knowledge of this rare tree species. Genetic structure with no/low $M$. × domestica influence about 80 to 100 years ago - was calculated, allowing a better comparison of populations and collections with special respect to place of origin. Our intention was to remove or at least reduce blurring due to hybridization and to escape from cultivation to provide a better insight to any provenance effects. Existing differences in domestic influence among samples living in the wild, ranging from about zero to $30 \%$ (see Table 2), stressed the necessity to proceed this way.

As expected, genetic diversity was slightly higher in apples including hybrid and feral $M d$ trees (WAGNER et al., 2004; WAGNER, 2008). Even in pure M. sylvestris (this study), diversity was high compared to other species. The mean number of alleles per locus was 2.68 (2.75, Germany only) at population level, and 3.10 at species level, which clearly increased the value of 1.55 mentioned for dicotyledonous species (MÜLLER-STARCK, 1996). In Prunus avium, another wild fruit tree, 1.4 alleles per locus on average have been observed in 5 French populations (MARIETTE et al., 1997). However, this value is expected to be that low due to the relatively small number of polymorphic loci analysed. In Sorbus aucuparia, another Rosaceae:Maloideae, 2.25 alleles per locus have been averaged over 17 populations (RASPE and JACQUEMART, 1998). Diversity in wild apple was similar to two main broadleaves in Central Europe; to Quercus robur in Switzerland (FINKELDEY and BoNFILS, 2001) or Europe (ZANETTO et al., 1994) harbouring A/L quotients of 2.70 , and to Fagus sylvatica in Germany with A/L quotients ranging from 2.3 (MÜLLER-STARCK, 1991) and 2.57 (SANDER et al., 2001) to 2.85 (Sander et al., 2000). Compared to other Malus species, the mean number of alleles per locus for $M$. sylvestris growing in Germany was identical to $M$. sieversii (2.75) (LAMBOY et al., 1996), well-known for its very high variability (ForsLine et al., 2003), and almost identical to $M$. × domestica, old cultivars (2.78) (WAGNER et al., 2004). Allelic diversity was lower in the North American Malus species $M$. fusca, $M$. ioensis (2.08), $M$. coronaria and M. angustifolia (1.75) (DiCKSON et al., 1991).

In comparison to average diversity given by classical parameters for long-lived woody perennials $(\mathrm{P}=49.3 \%$ [65.0\%], $\mathrm{A} / \mathrm{L}=1.76$ [2.22], $\mathrm{H}_{\mathrm{e}}=0.148$ [0.177] at the population [species] level (HAMRICK et al., 1992)), genetic diversity estimates are clearly higher in $M$. sylvestris within all populations in this study and within species $\left(\mathrm{P}=90 \%\right.$ [90\%], $\mathrm{A} / \mathrm{L}=2.68$ [3.10], $\mathrm{H}_{\mathrm{e}}=0.360$ [0.369], see Table 4). In particular, the expected panmictic heterozygosity in $M s$ is very high, and more than twice that value averaged over long-lived woody plants. The values of $\mathrm{H}_{\mathrm{e}}$ reported for wild cherry (Prunus avium) are approximately that high, especially when referring to trees growing in the Rhineland-Palatinate (KowNATZKI, 2002). Values $\left(\mathrm{H}_{\mathrm{e}}\right)$ reported for beech (Fagus sylvatica) match or are slightly higher (SANDER et al., 2001) than those values measured for wild apple. On average heterozygosity of forest trees is 20 to $23 \%$ (KONNERT, pers. comm.). In sessile oak (Quercus petraea) isozyme-based $\mathrm{H}_{\mathrm{e}}$ was observed to be 0.25 (FInKELDEY, 2001). For comparison, microsatellite-based $\mathrm{H}_{\mathrm{e}}$ in the same species was observed to be 0.86 (JENSEN et al., 2003, cit. from LARSEN et al., 2006), showing the different level of both types. The aforementioned high value is in line with values found for Malus sylvestris $\left(\mathrm{H}_{\mathrm{e}}=0.78\right.$ : LARSEN et al., 2006; $\mathrm{H}_{\mathrm{e}}=$ 0.72: COART et al., 2003).

The high level of genetic variation within species and populations observed in the present study confirms the expectations for species like $M$. sylvestris with large geographical ranges, an outcrossing breeding system and seed dispersal by animals (HAMRICK et al., 1992).

In most samples the fixation coefficient is close to zero, indicating that inbreeding effects probably do not occur (KONNERT and BAUER, 2001) and mating is random in those wild apple populations. In Rhineland-Palatinate weak inbreeding may explain the moderately positive F-value which reflects preferred mating of neighbouring trees. In North Rhine-Westphalia the F-value is 0.104 (see Table 4), which matches the mean value $\left(\mathrm{F}_{\mathrm{IS}}=0.105\right)$ for wild samples in Belgium (COART et al., 2003). NW is a large state in Germany where remaining apple trees have been sampled from scattered districts that never formed one random mating population. From this it is assumed, according to Belgium conditions that a Wahlund effect may have occurred, resulting in a shortage of heterozygotes.

Differentiation among the five samples of the native species is low as revealed by $\delta=0.089$ (see Table 5). Similar or lower mean allelic differentiation values $(\delta)$ are reported for other tree species: e. g. 0.091 for Prunus avium (KowNATZKI, 2002); 0.062 for both races, 0.036 for coastal races only of Pseudotsuga menziesii (LEINEMANN et al., 2001) and 0.049 for $P$. menziesii (LEINEMANN, 1996); 0.049 for Fagus sylvatica (SANDER et al., 2001); 0.045 for Quercus robur and 0.042 for Quercus petraea (FINKELDEY and BoNFILs, 2001). The aforementioned values may reflect the different pollination type. Roughly, insects work very effective within populations and less between. Entomophile species like wild apple and wild cherry are restricted in their distribution of genetic information by the pollinator behaviour. They showed a higher differentiation than main tree species from which pollen can be transported by wind over large distances. The complexity of multiple mechanisms influencing spatial genetic structure is described in JoLIVET et al. (2011). The subpopulation in Saxony with the lowest 
$\mathrm{d}_{\mathrm{j}}$-value (0.074) represents best the wild apple investigated in this study. The most genetic differentiated subpopulation is that in Rhineland-Palatinate, which possibly has some special genetic information indicating specific genetic processes.

Differentiation revealed by gene pool distance $\left(\mathrm{d}_{0}\right)$ between pairs of $M s$ samples ranged from 0.065 to 0.148 (for comparison $Q$. petraea: $0.050-0.163$ and $Q$. robur: 0.067-0.194, HERZOG, 1998), and reflected the geographical location of populations to a certain extent. One could have expected RP and ST to be genetically similar given the similar ecological conditions e. g. flood plains. On the other hand, ST and SN should not be similar because these sites differ much in elevation. In fact, the two geographically neighbouring populations in the west, i.e. RP and L, and in the east, i.e. ST and SN, were genetically very similar. The sample from NW does not fit into any geographic pattern, probably because this sample does not represent a population in reproductive sense but a collection of trees from a broad, scattered area. In addition, the pattern of frequencies of alleles specific to $M s$ (see Table 6) also matches the geographical pattern described beforehand.

Correspondence between genetic and geographic distance of populations has also been observed for oak by FinKELDEY (2001) and hazelnut by LEINEMANN et al. (2012). This correspondence may be due to the mechanisms of gene flow, i.e. pollen and seed dispersal, which are very much distance-sensitive.

\section{Aspects concerning gene conservation}

Studies of this kind may be helpful for the gene conservation of Malus sylvestris. With the information available now, a quantitative basis for conservation activities exists. Conservation measures based on quantitative data will be essential especially for rare tree species, which still are little investigated. Results achieved here and in like studies in Belgium and Denmark do not support the assumption that apples from Eurasia comprise one panmictic population (STEPHAN et $a l ., 2003)$. The clear differentiation of putative $M s$ and $M d$ into two separate gene pools justifies treating the European wild apple as a distinct genetic resource. Differences in the level of recent hybridization between samples and the correspondence between genetic and geographic distance in pure natural $M s$ populations indicate that conservation measures should be performed at the local level and adapted to the local situation. Thus, the consideration of provenances appears to be relevant. The use of in situ populations in long-term management programs supports continued adaptation, and hence dynamic conservation practices given unpredictable environmental futures (KJÆR et al., 2004). The results of this study must be seen in connection with the amendment of the Federal Nature Conservation Law (BNatSchG) in Germany that will regulate the use of native woody plants of regional origin (see LEINEMANN et al., 2012).

The gain in knowledge of the Ms intraspecific morphological variability can be expanded to other traits and can support practical conservation work in the field.

\section{Acknowledgements}

We thank Christine Geibel and Heike RiBbeck for their excellent work in the laboratory. We are grateful to Prof. Manfred Fischer, Meinolf Hammerschmidt and Dr. ERIC SCHULTE for providing plant material (reference purpose). Many thanks are given to Dr. FrankA HuTH for measuring some cultivar fruits. The kind and efficient support of Prof. NORMAN WEEDEN by many discussions regarding apples is highly appreciated. We thank Prof. HANs HatTemer very much for his valuable comments to a previous version of the manuscript. Two anonymous reviewers gave helpful suggestions and comments. Helen Desmond helped to improve English of the text substantially.

\section{Author Contributions}

IW conceived and designed the experiments. WDM, HPS, MW, PP, IW searched for funding. IW performed the experiments and analysed the data. WDM, PL, HPS, MW, PP, MB, IW contributed plant materials/morphological data. IW wrote the paper.

\section{References}

Beekman, M. and F. L. W. Ratnieks (2000): Long range foraging by the honey-bee, Apis mellifera L. Funct. Ecol. 14, 490-496.

BERG, E. E. and J. L. HAMrICK (1997): Quantification of genetic diversity at allozyme loci. Can. J. For. Res. 27, 415-424.

Binder, M. (2010): Morphologische und lichtökologische Untersuchungen an einem Wildapfelvorkommen (Malus sylvestris (L.) MILL.) im unteren Osterzgebirge. Diplomarbeit TU Dresden, Fak. Forst-, Geo- \& Hydrowissenschaften, Institut für Waldbau und Forstschutz.

BINDER, M., I. WAGNER und S. WAGNER (2011): Lichtökologische und morphologische Untersuchungen an WildApfel (Malus sylvestris [L.] MiLL., Rosaceae). Mitt. Deutsch. Dendrol. Ges. (MDDG) 96, 119-124.

Ble (Bundesanstalt Für Landwirtschaft Und ERNÄHRUNG) (2013): Erfassung und Dokumentation genetischer Ressourcen seltener und gefährdeter Baumarten in Deutschland. Teillos 2: Wild-Apfel (Malus sylvestris) und Wild-Birne (Pyrus pyraster). Eberswalde: Landeskompetenzzentrum Forst. http://www.ble.de/ DE/08_Service/03_Pressemitteilungen/2013/130425_ Wildapfel.html.

BRÄUER, G. und B. KRUMmHAAR (2004): 25 Jahre UNESCO-Biosphärenreservat Flusslandschaft Mittlere Elbe. Augenblick - Zeitung für das Biosphärenreservat 1 (8), 4-5.

Chevreau, E. and F. Laurens (1987): The pattern of inheritance in apple (Malus $\times$ domestica BoRKH.): further results from leaf isozyme analysis. Theor Appl Genet 75, 90-95.

Coart, E., X. Vekemans, M. J. M. Smulders, I. Wagner, J. Huylenbroeck, E. Bockstaele and I. RoldánRUIZ (2003): Genetic variation in the endangered wild apple (Malus sylvestris (L.) MILL.) in Belgium as revealed by amplified fragment length polymorphism and microsatellite markers. Mol. Ecol. 12, 845-857. 
Coart, E., S. Van Glabeke, M. De Loose, A. S. Larsen and I. ROLDAN-RUIZ (2006): Chloroplast diversity in the genus Malus: new insights into the relationship between the European wild apple (Malus sylvestris (L.) Mill.) and the domesticated apple (Malus domestica BoRKH.). Molecular Ecology 15, 2171-2182.

Cornille, A., P. Gladieux, M. J. M. Smulders, I. RoldanRUIZ, F. LAURENS et al. (2012): New Insight into the History of Domesticated Apple: Secondary Contribution of the European Wild Apple to the Genome of Cultivated Varieties. PLoS Genet 8, 1-13.

CREsswell, L. E. (1997): Spatial heterogeneity, pollinator behaviour and pollinator-mediated gene flow: bumblebee movements in variously aggregated rows of oil-seed rape. Oikos 78, 546-556.

Dickson, E. E., S. KResovich and N. F. WeEden (1991): Isozymes in North American Malus (Rosaceae): Hybridization and Species Differentiation. Systematic Botany 16 (2), 363-375.

Ellstrand, N. C. (2003): Current knowledge of gene flow in plants: implications for transgene flow. Philos. Trans. R. Soc. Lond. Biol. Sci. 358, 1163-1170.

Evanno, G., S. Regnaut and J. Goudet (2005): Detecting the number of clusters of individuals using the software STRUCTURE: a simulation study. Molecular Ecology 14, 2611-2620.

Finkeldey, R. und P. Bonfils (2001): Genetische Variation in Eichenbeständen (Quercus spp.) der Schweiz. Tagungsbericht zur 24. Internationalen Tagung der AG für Forstgenetik und Forstpflanzenzüchtung. Sächsische Landesanstalt für Forsten, Pirna, 203-211.

FinKELDEY, R. (2001): Genetic Variation of Oaks (Quercus spp.) in Switzerland. 2. Genetic Structures in "Pure" and "Mixed" Forests of Pedunculate Oak (Q. robur L.) and Sessile Oak (Q. petraea (Matt.) Liebl.). Silvae Genetica 50, 22-30.

FischeR, M. (1995): Farbatlas Obstsorten. Ulmer. ISBN 3-8001-5542-7.

Forsline, P. L., H. S. Aldwinckle, E. E. Dickson, J. J. LuBY and S. C. Hokanson (2003): Collection, Maintenance, Characterization and Utilization of Wild Apples of Central Asia. In: J. JANICK et al. (eds.): Wild apple and fruit trees of Central Asia. Hort. Rev. - Wiley. New York 29, 1-61.

GILlET, E. M. (2010): GSED - "Genetic structures from electrophoresis data". User's manual. Version 1.1h Aug.'01. Institute of Forest Genetics and Forest Tree Breeding, Göttingen, Germany. http://www.uni-goettingen.de/de/95607.html.

GREGORIUS, H.-R. (1987): The relationship between the concepts of genetic diversity and differentiation. Theor. Appl. Genet. 74, 397-401.

HAMrick, J. L., M. J. W. GOdT and S. L. Sherman-Broyles (1992): Factors influencing genetic diversity in woody plant species. New Forests 6, 95-124.

HarRis, S. A., J. P. Robinson and B. E. Juniper (2002): Genetic clues to the origin of the apple. Trends in Genetics 18, 426-430.

HARRISON, N. and R. J. HARRISON (2011): On the evolutionary history of the domesticated apple. Nat Genet 43, 1043-1044.

Hattemer, H. H., F. Bergmann und M. Ziehe (1993): Einführung in die Genetik für Studierende der Forstwissenschaft. J.D. Sauerländer's Verlag, Frankfurt am Main.
HATtEmeR, H. H. und H.-R. GREGORIUs (1993): Genetische Anforderungen an Maßnahmen zur Arterhaltung. Forstarchiv 64, 44-49.

Heinze, B. (1997): A PCR Marker for a Population deltoides allele and its use in studying introgression with native European Populus nigra. Belgian Journal of Botany 129, 123-130.

HerzoG, S. (1998): Genetische Strukturen mitteleuropäischer Stieleichen- (Quercus robur) und Traubeneichenpopulationen (Quercus petraea) sowie deren Bedeutung im Rahmen waldbaulicher Entscheidungen. Habilitationsschrift, Georg-August-Universität, Göttingen.

Hokanson, S. C., J. R. McFerson, P. L. Forsline, W. F. Lamboy, J. J. Luby, A. D. DJangaliev and H. S. AlDWINCKLE (1997): Collection and Managing Wild Malus Germplasm in its Center of Diversity. HortScience, Vol. 32(2), 173-176.

Jolivet, C., A. M. Höltken, H. Liesebach, W. Steiner and B. DEGEN (2011): Spatial genetic structure in wild cherry (Prunus avium L.): I. variation among natural populations of different density. Tree Genetics \& Genomes 7: 271-283.

KJÆR, E. D., W. Amarel, A. Yanchuk and L. Graudal (2004): Strategies for conservation of forest genetic resources. In: FAO, FLD, IPGRI (eds) Forest genetic resources conservation, management. Vol 1: overview, concepts, systematic approaches. International Plant Genetic Resources Institute, Rome, pp 5-24.

Kleinschmit, J. R. G., B. Hosius und L. Leinemann (2012): Gefährdung von Wildapfelsamenplantagen durch Genfluss. Forstarchiv 83 (1), 19-25.

Konnert, M. und M. BAUER (2001): Auswirkungen von Durchforstungen auf die genetische Struktur von Beständen am Beispiel der Fichte (Jungdurchforstung) und Buche (Altdurchforstung). Tagungsbericht, Sächsische Landesanstalt für Forsten, 151-157.

Korban, S. S. (1986): Interspecific hybridization in Malus. HortSience 21, 41-48.

KownATZKI, D. (2002): Asexuelle und sexuelle Reproduktion bei der Vogelkirsche (Prunus avium L.). Disser tation der Fakultät für Forstwissenschaften und Waldökologie der Georg-August-Universität Göttingen. http://webdoc.sub.gwd.de/diss/2002/kownatzki/index. html.

Kugler, H. (1970): Blütenökologie. 2. Aufl. Gustav Fischer Verlag, Stuttgart, Germany.

KutzelnigG, H. (1995): Malus. In: Hegi, G.: Illustrierte Flora von Mitteleuropa. Bd. IV, Teil 2B, 298-328.

Lamboy, W. F., J. Yu, P. L. Forsline and N. F. Weeden (1996): Partitioning of allozyme diversity in wild populations in Malus sieversii L. and implications for germplasm collections. J. Amer. Soc. Hort. Sci. 121, 982-987.

Larsen, A. S., C. B. Asmussen, E. Coart, D. C. Olrik and E. D. KJÆR (2006): Hybridization and genetic variation in Danish populations of European crab apple (Malus sylvestris). Tree Genet. Genom. 2, 86-97.

LARSEn, A. S., M. Jensen and E. D. KJÆR (2008): Crossability between wild (Malus sylvestris) and cultivated $(M$. $\times$ domestica) apples. Silvae Genetica 57, 3, $127-130$

LARSen, A. S. and E. D. KJÆR (2009): Pollen mediated gene flow in a native population of Malus sylvestris and its implication for contemporary gene conservation management. Conserv Genet 10, 1637-1646. 
Leinemann, L. (1996): Genetic Differentiation of Damaged and Healthy Douglas-Fir Stands in Rheinland-Pfalz with Respect to Their Origin. Silvae Genetica 45, 250-256.

Leinemann, L., B. Hosius and H.-P. Schmitt (2001): Genetische Untersuchungen zur Früherkennung ungeeigneter Douglasienbestände. Tagungsbericht, Sächsische Landesanstalt für Forsten, 216-222.

Leinemann, L., B. Hosius and W. Steiner (2012): Hasel: Genetische Analysen stützen ausgewiesene Vorkommensgebiete. TASPO 1 (47).

Leinemann, L., W. Steiner, B. Hosius, O. Kuchma, W. ARenhövel, B. Fussi, B. HAAse, R. Kätzel, M. RogGe, R. Finkeldey (2012): Genetic variation of chloroplast and nuclear markers in natural populations of hazelnut (Corylus avellana L.) in Germany. Plant Syst Evol 298, DOI 10.1007/s00606-012-0727-0.

MaliepaARD, C., F. H. Alston, G. van Arkel, L. M. Brown, E. Chevreau, F. Dunemann, K. M. Evans, S. Gardiner, P. Guilford, A. W. van Heusden, J. Janse, F. Laurens, J. R. Lynn, A. G. Manganaris, A. P. M. DEN NiJs, N. Periam, E. Rikkerink, P. Roche, C. Ryder, S. SAnsavini, H. Schmidt, S. TARTARini, J. J. VerhaEGH, M. VRIELINK-VAN GINKEL and G. J. KING (1998): Aligning male and female linkage maps of apple (Malus pumila MiLL.) using multi-allelic markers. Theor Appl Genet 97, 60-73.

Manganaris, A. G. and F. H. Alston (1987): Inheritance and linkage relationships of glutamate oxaloacetate transaminase isoenzymes in apple. 1. The gene GOT-1, a marker for the $\mathrm{S}$ incompatibility locus. Theor Appl Genet 74, 154-161.

Mariette, S., M. Lefranc, P. Legrand, D. TANeyhill, N. Frascaria-Lacoste and N. Machon (1997): Genetic variability in wild cherry populations in France. Effects of colonizing processes. Theor Appl Genet 94, 904-908.

Micheletti, D., M. Troggio, F. Salamini, R. Viola, R. VELASCO et al. (2011): On the evolutionary history of the domesticated apple. Nat Genet 43, 1044-1045.

Morgan, J. and A. Richards (1993): The book of apples. Ebury Press, London.

MÜlleR-STARCK, G. (1991): Survey of genetic variation as inferred from enzyme gene marker. In: (MÜLLER-STARCK, G. \& ZIEHE, M. eds.) Genetic Variation in European populations of forest trees. Sauerländer's Verlag, Frankfurt am Main, 20-37.

MÜLLER-STARCK, G. (1996): Beiträge der Forstgenetik zur nachhaltigen Waldbewirtschaftung. In: MÜLLER-STARCK (Hrsg.): Biodiversität und nachhaltige Forstwirtschaft. Ecomed, Landsberg.

Pritchard, J. K., M. Stephens and P. Donnelly (2000): Inference of population structure using multilocus genotype data. Genetics 155, 945-959.

PRITChaRD, J. K., X. WEN and D. FALUSH (2007): Documentation for structure software: Version 2.2 ; http://pritch. bsd.uchicago.edu/software.

RASPE, O. and A.-L. JACQUEMART (1998): Allozyme diversity and genetic structure of European populations of Sorbus aucuparia L. (Rosaceae:Maloideae). Heredity 81, 537-545.

Reim, S., A. Proft, S. Heinz and M. Höfer (2012): Diversity of the European indigenous wild apple Malus sylvestris (L.) MILL. in the East Ore Mountains (Osterzgebirge), Germany: I. Morphological characterization. Genet Resour Crop Evol 59, 1101-1114.
Reim, S., A. Proft, S. Heinz and M. HöFER (2013): Conservation measures for Malus sylvestris in the East Ore Mountains, Germany. Forstarchiv 84, 144-151.

REMMY, K. und F. GRUBER (1993): Untersuchungen zur Verbreitung und Morphologie des Wild-Apfels (Malus sylvestris (L.) Mill.). Mitt. Dtsch. Dendrol. Ges. 81, 71-94.

Robinson, J. P., S. A. Harris and B. E. Juniper (2001): Taxonomy of the genus Malus Mill. (Rosaceae) with emphasis on the cultivated apple, Malus $\times$ domestica Borkh. Plant Systematic and Evolution 226, 35-58.

SANDER, T., S. KÖNIG, G. M. Rothe, A. JANßEN and H. WEISGERBER (2000): Genetic variation of European beech (Fagus sylvatica L.) along an altitudinal transect at mount Vogelsberg in Hesse, Germany. Molecular Ecology 9, 1349-1361.

SANDER, T., G. M. Rothe, H. Weisgerber and A. JANßEN (2001): Allelic and genotypic variation of 13 European beech (Fagus sylvatica L.) - populations in Hesse, Germany. Forest Genetics 8 (1), 13-24.

SchmidT, P. A. (2006): Bäume und Sträucher Kaukasiens. Teil 5: Laubgehölze der Familien Ranunculaceae (Hahnenfußgewächse) bis Rutaceae (Rautengewächse). MDDG 91, 21-56.

StEFFAn-Dewenter, I. and A. KuHN (2003): Honeybee foraging in differentially structured landscapes. Proc. $R$. Soc. Lond. Biol. Sci. 270, 569-575.

Stephan, B. R., I. WAGNER and J. Kleinschmit (2003): EUFORGEN Technical guidelines for genetic conservation and use for wild apple and pear (Malus sylvestris and Pyrus pyraster), International Plant Genetic Resources Institute, Rome, Italy.

Vanden Broeck A., V. Storme, J. E. Cottrell, W. BoerJan, E. VAN Bockstaele, P. Quataert and J. VAN SLYCKEN (2004): Gene flow between cultivated poplars and native black poplar (Populus nigra L.): a case study along the river Meuse on the Dutch-Belgian border. For Ecol Manage 197, 307-310.

Velasco, R., A. Zharkikh, J. Affourtit, A. Dhingra, A. Cestaro et al. (2010): The genome of the domesticated apple (Malus $\times$ domestica BorkH.). Nat Genet 42 , 833-839.

WAGNER, I. (1996): Zusammenstellung morphologischer Merkmale und ihrer Ausprägungen zur Unterscheidung von Wild- und Kulturformen des Apfel- (Malus) und des Birnbaumes (Pyrus). Mitt. Dtsch. Dendrol. Ges. 82, 87-108.

WAGneR, I. (2005): Malus sylvestris (L.) Mill. In: (Hrsg. SchütT, WeISGERBER, LANG, ROLOFF, STIMm) Enzyklopädie der Holzgewächse. 42. Erg Lfg. 12/05, Kap. III-2, 1-16, Ecomed Biowissenschaften.

WAGNER, I. (2008): Genetische Analysen an Wild-Äpfeln im Biospärenreservat Mittelelbe. In: (Hrsg. Landesamt für Umweltschutz Sachsen-Anhalt) Berichte des Landesamtes für Umweltschutz Sachsen-Anhalt. Sonderheft 2, 29-36. http:/www.sachsen-anhalt.de/fileadmin/ Elementbibliothek/Bibliothek_Politik und Verwaltung/Bibliothek_LAU/Wir_ueber_uns/Publikationen/ Sonderhefte_der_Berichte_des_LAU/Dateien/Foerderung_von_Wildobst_und_Feld-Ulme.pdf.

WAGNER, I. (2011): Assessing the distance to cultivation in wild fruit - Example Malus sylvestris (L.) MiLL. In: (Hrsg. MAURER und HAASE) Holzproduktion auf forstgenetischer Grundlage im Hinblick auf Klimawandel und Rohstoffverknappung. Mitt. FAWF RP 69, 187-194. [in German, English abstract] http://www. wald-rlp.de/fileadmin/website/fawfseiten/fawf/downloads/Mitteilungen/Mitteilung_69-11.pdf. 